\section{Biodiesel Production by Transesterification of Tallow Fat Using Heterogeneous Catalysis}

\author{
B. Vafakish* and M. Barari
}

Chemical, Polymeric and Petrochemical Technology Development Research Division, Research Institute of Petroleum Industry, P.O. Box 14115-143, Tehran, Iran
DOI: $10.15255 /$ KUI.2016.002

KUI-5/2017

Professional paper Received January 27, 2016 Accepted March 15, 2016

\begin{abstract}
\| Abstract
Biodiesel is an eco-friendly alternative diesel fuel prepared from domestic renewable resources i.e. vegetable oils and animal fats. In this process, biodiesel is produced by transesterification of triglycerides present in animal fat or vegetable oils, by displacing glycerine with a low molar mass alcohol using homogeneous or heterogeneous catalysis. The resulting ester, after mixing with diesel fuels, has physicochemical properties similar to those of conventional fuels. In this work, the batch process of biodiesel production has been studied using tallow fat as raw material with methanol and a heterogeneous catalyst. The quality of the produced biodiesel was evaluated by the determination of important properties, such as viscosity, flash point, cetane number, oxidation stability, glycerine content, acid value, etc. The produced biodiesel was found to demonstrate fuel properties within the ranges recommended by the ASTM D6751.
\end{abstract}

$\|$ Keywords

Biodiesel, tallow fat, alcoholysis, heterogeneous catalysis, transesterification

\section{Introduction}

There is a growing worldwide concern for environmental protection and the conservation of non-renewable natural resources. The use of fuels made from biomass, such as biodiesel and bioethanol, can help satisfy the need for energy forms from renewable sources. ${ }^{1,2}$ Biodiesel is a liquid fuel similar to petroleum diesel in combustion properties, but really free of sulphur, which makes it a cleaner burning fuel compared to petroleum diesel. In other words, it is an environmentally friendly alternative to fossil fuels. Biodiesel is produced by alcoholysis of edible or non-edible fats and oils e.g. coconut, castor, and cotton seed oil or animal fat, like tallow fat..$^{3-5}$ In the alcoholysis process, the oil or fat is transesterified with a light alcohol e.g. methanol, and the product is a mixture of fatty acid methyl ester (FAME) and glycerine, which are used separately as fuel after puri- fication. 6,7 Some factors, including catalyst concentration, free fatty acid and moisture content or glycerine removal influence the rate of reaction. Scheme 1 represents the transesterification reaction. ${ }^{8}$ In different countries, many resources of oils and fats are utilized to produce biodiesel.

There are many industrial methods for the production of biodiesels, which are classified into two groups: chemical and biotechnological techniques. ${ }^{9}$

The biotechnological methods are not independent methods. In fact, they are a mixture of biotechnology and chemistry. For example, there is a particular kind of bacteria, which produce triglyceride-rich walls that are removed and chemically transformed to biodiesel. Whereas, in chemical techniques, the animal or plant oils and fats are chemically transformed into biodiesel.

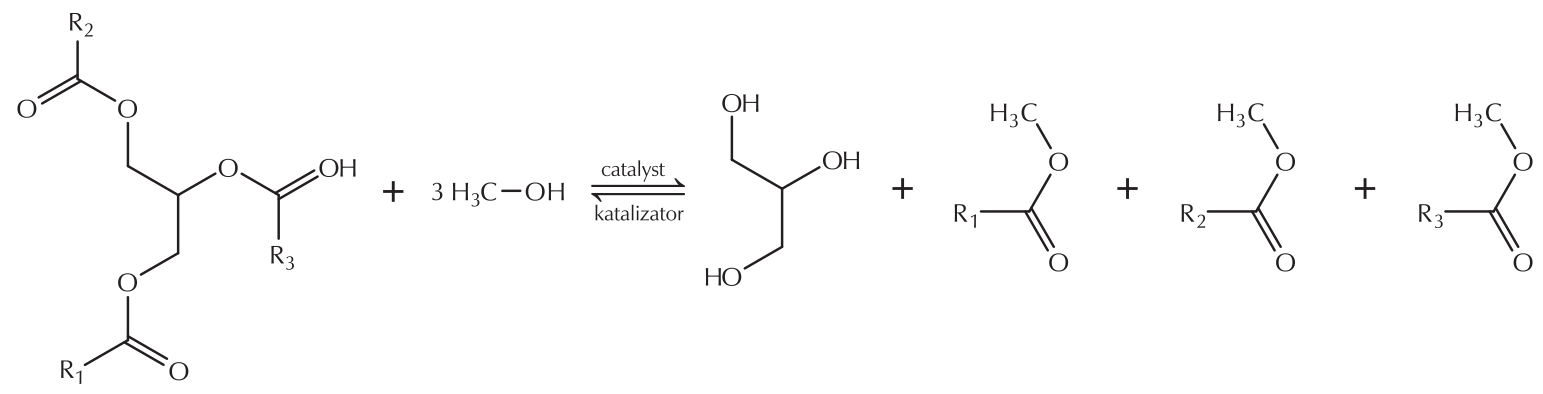

Scheme 1

Shema 1

"Corresponding author: Bahareh Vafakish, Ph. D.

e-mail: vafakishb@ripi.ir 
The physical and chemical properties, pros and cons, combustion power, and other specifications of biodiesels are compared with diesel fuels, which exhibit lower emission of carbon monoxide, carbon dioxide, sulphur dioxide, particles, aromatic hydrocarbons, and harmful substances into the environment.

Nowadays, most biodiesel is produced by the transesterification of triglycerides of refined/edible-type oils and fats using methanol and an alkaline catalyst $(\mathrm{NaOH}, \mathrm{NaOMe}$, $\mathrm{KOH}) .{ }^{10,11}$ However, production costs are still rather high compared to petroleum-based diesel fuel production costs. ${ }^{12}$ To lower the costs and make biodiesel competitive with petroleum-based diesel, less expensive processes should be used. ${ }^{13}$ In this study, a batch reaction was selected and two key factors, including time and catalyst concentration, were involved in the reaction of tallow fat with methanol. lon-exchange resins were used as the heterogeneous catalyst. Compared to other catalysts, these are high-capacity and macroporous catalysts, which can be regenerated and tolerate severe conditions without degradation. ${ }^{14}$ The main economic advantage of using these catalysts is the simplicity of their isolation from the reaction mixture to purify the viscous product, which makes the reaction a short time experience in comparison with similar processes.

\section{Experimental}

\section{Materials and equipment}

The used tallow fat was a commercial-grade fat with the following mixture: palmitic acid $26 \%$, oleic acid $43 \%$, linoleic acid $3 \%$, stearic acid $14 \%$, tetracosnoic acid $1 \%$, and the remainder $8 \%$. A commercially prepared ion-exchange strongly-basic polymeric resin based on crosslinked styrene divinylbenzene copolymer containing quaternary ammonium groups was used as heterogeneous catalyst under the brand name of Amberlyst ${ }^{\mathrm{TM}} \mathrm{A} 26 \mathrm{OH}$ from Dow Company. The total exchange capacity of the resin was $\geq 0.8 \mathrm{~mol} \mathrm{I}^{-1}$ and hydroxide functional groups were activated before the reaction. Other materials, e.g. methanol, was Merck synthetic grade.

\section{Apparatus}

The transesterification reaction was carried out in a $2 \mathrm{dm}^{3}$ 3-neck round-bottom glass flask with a mechanical overhead stirrer, a thermometer, an electrothermal heating mantle and a nozzle to flush the nitrogen gas. The top of the reactor was fitted with a condenser to condense the methanol; Connected to the condenser was a U-shaped tube filled with anhydrous calcium sulphate blocked by cotton on both sides of the tube to ensure entrance of moisture-free air into the system. The stirrer was equipped with a stainless steel shaft and four anchor-shaped stirrer blades at two different heights, one at the end of the shaft and the other in the lower third of the shaft. There were also four small metallic mesh bags attached to the end of each blade filled with activated heterogeneous catalyst.

The FT-IR spectrophotometer was Shimadzo IRTracer-100. Nitrogen gas was taken during spectrum recording and classical infrared $\mathrm{KBr}$ plates were used for the measurements of the infrared spectra in the range of $400-4000 \mathrm{~cm}^{-1}$.

\section{Experimental procedure}

The tallow fat $(1 \mathrm{~mol}, 890 \mathrm{~g})$ was introduced into the flask established for the reaction (same amount in every reaction), which was equipped with a stirrer, heating mantle, thermometer, nitrogen line to flush nitrogen into the reactor before reaction, and filled bags of different amounts of activated heterogeneous catalyst. The top of the condenser was covered with a small balloon after nitrogen flushing to prevent air oxidation of fat at high temperature. Then, $192 \mathrm{~g}(6 \mathrm{~mol})$ of methanol was added into the flask. The reaction mixture was heated in a ventilated oven to gain a homogeneous reaction mixture on a heating plate taking this moment as time zero of the reaction. The molar ratio of methanol to vegetable oil was six, which corresponded to two times the stoichiometry. The temperature of the oven was increased from room temperature at a fixed rate $\left(5^{\circ} \mathrm{C} \mathrm{min}^{-1}\right)$ until it reached $65{ }^{\circ} \mathrm{C}$. The transesterification was carried out at reflux of methanol for the determined time.

The produced FAME was studied in the reaction time in the range of 60 to 500 minutes. The equivalent catalyst concentration was varied at 1, 1.7, 2.1, 2.3, 2.5, 2.7 moles per litre of fat. To assess the effectiveness of the catalyst separated from other contributing factors, each run was started with a fresh activated catalyst.

At the end, the product was allowed to cool for 20 minutes to separate it into two phases, the upper phase was FAME and the lower was a mixture of methanol and glycerine. The FAME was separated in a decanter and then washed with water. Vacuum was used to remove moisture or any other volatile impurities, like remaining methanol, from the reaction product. The weight of the obtained FAME was used to calculate the yield of the reaction. Elimination of the filtration step to remove the heterogeneous catalysts caged in the bags is an economical benefit of this method, bearing in mind that filtration of a viscous FAME is a time-consuming process at the industrial scale.

\section{Results and discussion}

\section{Catalyst concentration effect}

The effect of varying the amount of the catalyst was studied. The catalyst concentration, in terms of equivalent entities, was varied in the range of 1 to 3 moles $(1,1.7,2.1,2.3,2.5$, 
2.7) per litre of fat. As shown in Fig. 1, at first, the conversion increased with the increase in catalyst concentration from 1 to 2.2 moll $^{-1}$. However, with the further increase in catalyst amount from 2.2 to $3 \mathrm{moll}^{-1}$, there was no further increase in conversion. The reaction was conducted while the methanol to tallow fat amount-of-substance ratio was $6: 1$, and the reaction mixture under reflux. The reaction time of 500 minutes was selected for the full conversion of the tallow fat. Fig. 1 demonstrates that the concentration of $2.2 \mathrm{moll}^{-1}$ was the appropriate amount, and there was no noticeable reaction rate increase after that.

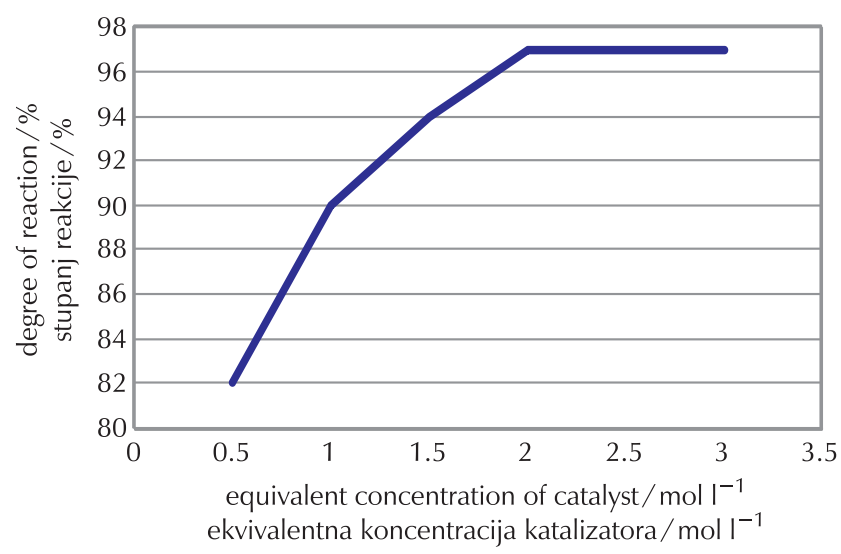

Fig. 1 -Catalyst concentration influence on the amount of the produced FAME in the refluxing methanol after 500 minutes while the methanol to tallow fat amountof-substance ratio was $6: 1$

Slika 1 - Utjecaj koncentracije katalizatora na količinu proizvedenih metilnih estera masnih kiselina (FAME) u refluksu metanola nakon 500 minuta uz množinski omjer metanola i loja $6: 1$

\section{Time effect}

Fig. 2 shows the conversion versus reaction time with two different catalyst concentrations on the progress of the reaction in the range of 60 to 500 minutes. The reaction was conducted while the methanol to tallow fat amount ratio was $6: 1$, catalyst concentration 1.7 and 2.2 moles per litre of fat, and reaction mixture under reflux. It could be seen from the plot that the conversion increased in the reaction time range from 60 to around 400 minutes while the reaction mixture was under reflux, and after that remained almost constant as a representative of a near equilibrium conversion. A noticeable higher conversion was achieved with $2.2 \mathrm{moll}^{-1}$ catalyst concentration in a shorter time. Thus, considering the economic items, this concentration was selected to decide on the appropriate reaction time. As can be seen, with this catalyst concentration, there was no noticeable FAME formation after 360 minutes.

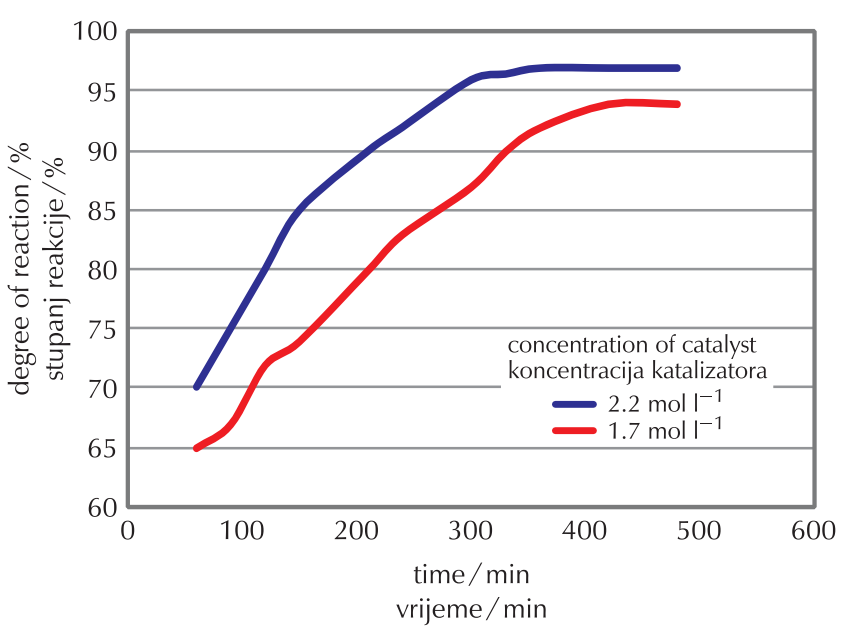

Fig. 2 - Influence of time on the amount of produced FAME in the refluxing methanol while the methanol to tallow fat amount-of-substance ratio was $6: 1$ with equivalent concentrations of catalyst 1.7 and $2.2 \mathrm{~mol}^{-1}$

Slika 2 - Utjecaj vremena na količinu proizvedenih metilnih estera masnih kiselina (FAME) u refluksu metanolua uz množinski omjer metanola prema loju $6: 1$ s ekvivalentnim koncentracijama katalizatora 1,9 i 2,5 $\mathrm{moll}^{-1}$

\section{FT-IR spectra}

FTIR provides an easy, precise, and fast approach to visualize the turnover from tallow fat during transesterification to FAME. ${ }^{15}$ The raw oil and the methyl esters are fairly strong absorbers in the infrared region, and caution was taken to ensure that the spectra were not saturated when performing the analysis. In both spectra, the ester carbonyl group stretching vibration at $1750 \mathrm{~cm}^{-1}$ is shown by strong bands, and the presence of the $\left(\mathrm{CH}_{2}\right)_{\mathrm{n}}$ group vibration bands is seen around $720 \mathrm{~cm}^{-1}$ (Fig. 3). The absence of a broad band at the $2500-3300 \mathrm{~cm}^{-1}$ region confirms the low moisture and free fatty acid content of the sample. ${ }^{16}$

The peak analysis of both spectra shows significant differences in the mid-IR region from $400-1500 \mathrm{~cm}^{-1}$ while both spectra were found qualitatively similar in the strong carbonyl signal and hydrocarbon chain. Long hydrocarbon chains and the carbonyl group remain unaffected during transesterification, but new signals are visible belonging to the methyl vibrations in the FAME. The transesterification produced the $-\mathrm{OCH}_{3}$ group, which is shown as one of the strongest impacts in the infrared spectrum as a narrow peak, which rides on the side of another peak in $1435 \mathrm{~cm}^{-1}$ due to the out-of-plane stretching in the FAME spectra. This peak gives a direct indication of the attachment of the methyl group of the methanol to the fatty acids of the triglycerides, and this peak is free of the influence of the alkyl group present in the FAME. The second difference can be seen around $1200 \mathrm{~cm}^{-1}$. The strong, broad signal at $1159 \mathrm{~cm}^{-1}$ in tallow fat will separate into two signals at 1168 and $1195 \mathrm{~cm}^{-1}$. 

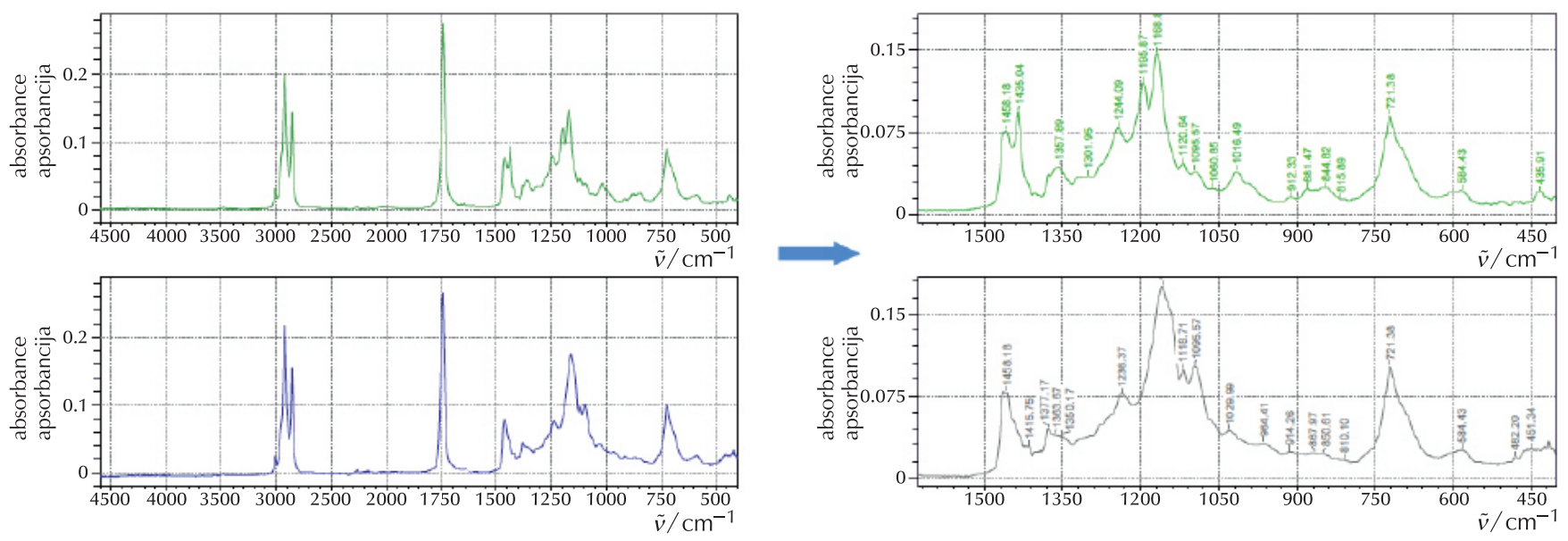

Fig. 3 - Upper spectra are the IR spectra of the FAME produced from tallow fat, and the lower for raw tallow fat. At the right, the extended view of the region $400-1500 \mathrm{~cm}^{-1}$ is shown. The new signal at $1435 \mathrm{~cm}^{-1}$ and splitting of the peaks at 1190 and $1430 \mathrm{~cm}^{-1}$ is clearly visible.

Slika 3 - Gornji IR-spektri pripadaju metilnim esterima masnih kiselina (FAME) proizvedenima iz loja, a donji spektri esterima proizvedenima su iz sirovog sala. Desno je prikazan detaljniji pogled na područje $400-1500 \mathrm{~cm}^{-1}$. Jasno je vidljiv novi signal na $1435 \mathrm{~cm}^{-1}$ i cijepanje vrhova na 1190 i $1430 \mathrm{~cm}^{-1}$.

\section{Study of the final product specification based on ASTM D6751}

Biodiesel is an efficient, clean, and $100 \%$ natural energy alternative to petroleum fuels. Among the many advantages of biodiesel fuel are the following: safe for use in all conventional diesel engines, offers the same performance and engine durability as petroleum diesel fuel, non-flammable and non-toxic, reduces tailpipe emissions, visible smoke and noxious fumes and odors. ${ }^{17}$

Table 1 shows the physicochemical characteristics of the produced biodiesel after purification based on ASTM D6751. This standard defines biodiesel as mono-alkyl es-

Table 1 - Biodiesel specification of this study according to ASTM D6751

Tablica 1 - Specifikacije biodizela u ovom istraživanju prema ASTM D6751

\begin{tabular}{|c|c|c|}
\hline $\begin{array}{l}\text { Items } \\
\text { Stavke }\end{array}$ & $\begin{array}{l}\text { Standard } \\
\text { Standard }\end{array}$ & $\begin{array}{l}\text { Result } \\
\text { Rezultat }\end{array}$ \\
\hline $\begin{array}{l}\text { appearance } \\
\text { izgled }\end{array}$ & - & $\begin{array}{l}\text { clear yellowish oily liquid } \\
\text { bistra žućkasta uljasta tekućina }\end{array}$ \\
\hline $\begin{array}{l}\text { flash point (closed cup) } \\
\text { plamište (zatvorena posuda) }\end{array}$ & $\min .93{ }^{\circ} \mathrm{C}$ & $104{ }^{\circ} \mathrm{C}$ \\
\hline $\begin{array}{l}\text { mass fraction of methanol } \\
\text { maseni udjel metanola }\end{array}$ & $\max .0 .20 \%$ & $0.12 \%$ \\
\hline $\begin{array}{l}\text { vol. fraction of water and sediment } \\
\text { obujamski udjel vode i sedimenta }\end{array}$ & $\max .0 .05 \%$ & $0.03 \%$ \\
\hline $\begin{array}{l}\text { kinematic viscosity }\left(40{ }^{\circ} \mathrm{C}\right) \\
\text { kinematička viskoznost }\left(40{ }^{\circ} \mathrm{C}\right)\end{array}$ & $1.9-6.0 \mathrm{~mm}^{2} \mathrm{~s}^{-1}$ & $5.6 \mathrm{~mm}^{2} \mathrm{~s}^{-1}$ \\
\hline $\begin{array}{l}\text { mass fraction of sulphated ash } \\
\text { maseni udjel sulfatnog pepela }\end{array}$ & $\max .0 .020 \%$ & $0.012 \%$ \\
\hline $\begin{array}{l}\text { cetan number } \\
\text { cetanski broj }\end{array}$ & $\min .47$ & 62 \\
\hline $\begin{array}{l}\text { acid number } \\
\text { kiselinski broj }\end{array}$ & max. $0.5 \mathrm{mg} \mathrm{KOH} \mathrm{/} 1 \mathrm{~g}$ FAME & $0.3 \mathrm{mg} \mathrm{KOH} / 1 \mathrm{~g}$ FAME \\
\hline $\begin{array}{l}\text { mass fraction of total glycerine } \\
\text { maseni udjel ukupnog glicerina }\end{array}$ & $\max .0 .24 \%$ & $0.15 \%$ \\
\hline $\begin{array}{l}\text { distillation temperature of } 90 \% \\
\text { temperatura destilacije } 90 \%\end{array}$ & $\max .360{ }^{\circ} \mathrm{C}$ & $325{ }^{\circ} \mathrm{C}$ \\
\hline $\begin{array}{l}w(\mathrm{Na} \text { and } \mathrm{K}) \\
w(\mathrm{Na} \text { i } \mathrm{K})\end{array}$ & $\max .5$ ppm & $1.2 \mathrm{ppm}$ \\
\hline $\begin{array}{l}\text { oxidation stability } \\
\text { stabilnost na oksidaciju }\end{array}$ & $\min .3 \mathrm{~h}$ & $7.2 \mathrm{~h}$ \\
\hline
\end{tabular}


ters of long-chain fatty acids derived from vegetable oils and animal fats. The type of alcohol used is not specified. Thus, mono-alkyl esters could be produced with any alcohol (methanol, ethanol, etc.) as long as it meets the detailed requirements outlined in the fuel specification. As it can be seen from Table 1, all of the specifications are in the standard range. The cetane number for the produced FAME was higher than that of the standard. The higher cetane number of the FAME over the specified limit make them attractive as an alternative to diesel fuels or cetane enhancers, where there is continuing stress on raising the cetane index of diesel fuel.

Derived from literature, the FAME will be mixed with fossil fuels. This mixing up to $30 \%$ was tested in motor engines and approved. According to the European Union standard, this mixing is accepted up to volume fraction of $5 \%$.

\section{Conclusion}

Biodiesel production from tallow fat by Amberlyst ${ }^{\mathrm{TM}} \mathrm{A} 26$ $\mathrm{OH}$ as heterogeneous catalyst was investigated in a stirred batch reactor. The results of this study, suggest that the optimum reaction conditions for the methanolysis of tallow fat is equivalent concentration of heterogeneous catalyst 2.2 mol $^{-1}$ and reaction time of 360 minutes for a biodiesel yield of 90-95\%. This method is easy and inexpensive, and requires no specific or precise equipment. The final product was a viscous, light yellow oil, with properties in the line with the prescribed ASTM standard.

\section{ACKNOWLEDGEMENT}

The authors are grateful to Kimyagaran Emrooz Chem. Ind. Co. (Tehran, Iran) for the financial support and preparation of the needed equipment for this project.

\section{List of abbreviations and symbols Popis kratica i simbola}

FAME - fatty acid methyl ester - metil-esteri masnih kiselina

$\tilde{v} \quad$ - wave number, $\mathrm{cm}^{-1}$ - valni broj, $\mathrm{cm}^{-1}$

\section{References Literatura}

1. A. Srivastava, R. Prasad, Triglycerides-based diesel fuels, Renew. Sustain. Energy Rev. 4 (2000) 111-133, doi: https://doi. org/10.1016/S1364-0321(99)00013-1.

2. R. A. Ferrari, V. S. Oliveira, A. Scabio, A Biodiesel from soybean: characterization and consumption in an energy generator, Quim. Nova 28 (2005) 19-23, doi: https://doi. org/10.1590/S0100-40422005000100004.

3. L. C. Meher, D. V. Sagar, S. N. Naik, Technical aspects of biodiesel production by transesterification - a review, Renew. Sustain. Energy Rev. 10 (2006) 248-268, doi: https://doi. org/10.1016/j.rser.2004.09.002.

4. J. Sheehan, V. Camobreco, J. Duffield, M. Graboski, H. Shpapouri, An Overview of Biodiesel and Petroleum Diesel Life Cycles ,U.S. Department of Energy, Office of Scientific and Technical Information, 1998 in http://www.biodiesel.com/ PDF/.pdf (accessed in April 30, 2008).

5. F. Ma, D. L. Clements, A. M. Hanna, Biodiesel fuel from animal fat. Ancillary studies on transesterification of beef tallow, Ind. Eng. Chem. Res. 37 (1998) 3768-3771, doi: https://doi. org/10.1021/ie980162s.

6. B. Freedman, E. H. Pryde, T. L. Mounts, Variables affecting the yields of fatty esters from transesterified vegetable, J. Am. Oil Chem. Soc. 61 (1984) 1638-1643, doi: https://doi. org/10.1007/BF02541649.

7. J. Van Gerpen, Biodiesel processing and production, Fuel Process. Technol. 86 (2005) 1097-1107, doi: https://doi. org/10.1016/j.fuproc.2004.11.005.

8. M. Garcia, A. Gonzalo, J. Arauzo, C. Simoes, Methanolysis and ethanolysis of animal fats: a comparative study of the influence of alcohols, CI \& CEQ 17 (2011) 91-97, doi: https:// doi.org/10.2298/CICEQ100224058G.

9. M. Veillette, M. Chamoumi, J. Nikiema, N. Faucheux, M. Heitz, Production of biodiesel from microalgae, in Zeeshan Nawaz and Shahid Naveed (Eds.), Advances in Chemical Engineering, InTech, 2012, pp. 245-268, doi: https://doi. org/10.5772/31368.

10. M. Di Serio, R. Tesser, M. Dimiccoli, F. Cammarota, M. Nastasi, E. Santacesaria, Synthesis of biodiesel via homogenous Lewis acid catalyst, J. Mol. Cat. A. Chem. 239 (2005) 111115, doi: https://doi.org/10.1016/j.molcata.2005.05.041.

11. A. S. Ramadhas, S. Jayaraj, C. Muraleedharan, Biodiesel production from high FFA rubber seed oil, Fuel 84 (2005) 335-340, doi: https://doi.org/10.1016/j.fuél.2004.09.016.

12. M. Fangrui, M. A. Hanna, Biodiesel Production: a review, Bioresour. Technol. 70 (1999) 1-15, doi: https://doi. org/10.1016/S0960-8524(99)00025-5.

13. Y. Zhang, M. A. Dubé, D. D. McLean, M. Kates, Biodiesel production from waste cooking oil: 1. Process design and technological assessment, Bioresour. Technol. 89 (2003) 1-16, doi: https://doi.org/10.1016/S0960-8524(03)000403.

14. M. D. Argyle, C. H. Bartholomew, Heterogeneous Catalyst Deactivation and Regeneration: A. Review, Catalysts 5 (2015) 145-269, doi: https://doi.org/10.3390/catal5010145.

15. W. B. Zhang, Review on analysis of biodiesel with infrared spectroscopy, Renew. Sust. Energy. Rev. 16 (2012) 60486058, doi: https://doi.org/10.1016/j.rser.2012.07.003.

16. A. Ivanoiu, A. Schmidt, F. Peter, L. M. Rusnac, M. Ungurean, Comparative Study on Biodiesel Synthesis from Different Vegetables Oils, Chem Bull "POLTEHNICA" Univ. 56 (2011) 94-98.

17. A. Srivastava, R. Prasad, Triglycerides-based diesel fuels, Renew. Energy. Rev. 4 (2000) 111-133, doi: https://doi. org/10.1016/S1364-0321(99)00013-1. 


\title{
SAŽETAK
}

\section{Proizvodnja biodizela heterogeno kataliziranom transesterifikacijom loja}

\author{
Bahareh Vafakish* i Mohammad Barari
}

Biodizel je ekološki prihvatljiva alternativa dizelskom gorivu, pripremljena iz domaćih obnovljivih izvora kao što su biljno ulje i životinjske masnoće. U tim procesima biodizel se proizvodi transesterifikacijom triglicerida prisutnim u životinjskoj masnoći ili u biljnim uljima zamjenom glicerina s alkoholima male molekulske mase koristeći se homogenom ili heterogenom katalizom. Ester nakon miješanja s dizelskim gorivima ima fizičko-kemijska svojstva slična konvencionalnim gorivima. Ovdje je istražena šaržna proizvodnja biodizela iz loja i metanola uz heterogeni katalizator. Kvaliteta biodizela ocjenjena je prema važnim svojstvima kao što su viskoznost, plamište, cetanski broj, oksidacijska stabilnost, sadržaj glicerina, kiselinski broj itd. Svojstva proizvedenog biodizela u skladu su sa standardima ASTM D6751.

Ključne riječi

Biodizel, loj, alkoholiza, heterogena kataliza, transesterifikacija

Polymer Science and Technology Division, Research Institute of Petroleum Industry, Synthesis of Polymers Group,

P.O. Box 14115-143, Teheran, Iran
Stručni rad

Prispjelo 27. siječnja 2016. Prihvaćeno 15. ožujka 2016. 